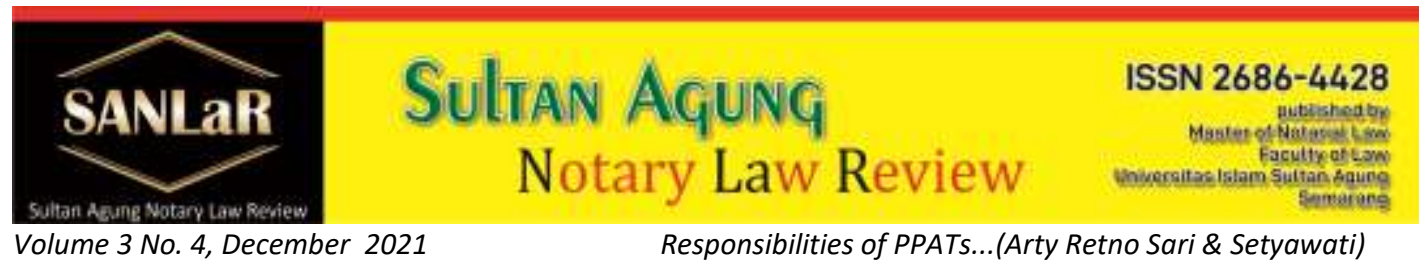

\title{
Responsibilities of PPATs who are Late in Registering Deeds Has Been Made to the Office of the National Land Agency
}

\author{
Arty Retno Sari $\left.{ }^{*}\right)$ and Setyawati**) \\ ${ }^{*}$ Faculty of Law, Universitas Islam Sultan Agung (UNISSULA) Semarang, E-mail: \\ arty.sari95@gmail.com
}

*) Faculty of Law, Universitas Islam Sultan Agung (UNISSULA) Semarang, E-mail: setyawatiham@gmail.com

\begin{abstract}
PPAT services as an authorized position are very useful for certain people, especially for people who do not understand the law. Some people who do not understand the law feel unable to handle the legal problems they face, given the limited data around the law. For quick access to PPAT-related matters, the national office must issue a receipt for submitting a registration application, for example, a deed from the PPAT and submit the file to the appropriate PPAT. This responsibility not only affects the progress of understanding or compliance with the law, but also considers the greater legal impact on PPAT's thoughts or behavior, both positive and negative. Because of the importance of evidence as a way of affirmation that can provide legal certainty and guarantee to the right holder, the making of a deed of transfer of land rights as a reason to follow land registration data through the sale and purchase of land rights must be in accordance with the timeframe previously specified in Article 40 paragraph (1) Government Regulation Number 24 of 1997 concerning Land Registration.
\end{abstract}

Keywords: Legal Consequences; PPAT Obligations; Legal Liability.

\section{Introduction}

According to Article 5 of Government Regulation Number 24 of 1997, the registration of land located throughout the territory of Indonesia is entrusted to the National Land Agency of the Republic of Indonesia, which stipulates that BPN shall carry out land registration. This is based on Presidential Decree No. 63 of 2013. Article 3 of the National Land Agency on Land Management. BPN RI has 
fulfilled its commitment to implement measures in the field of securing territorial rights, land registration, and environmental protection.

Article 6 of Government Regulation Number 24 of 1997 stipulates that BPN will carry out land registration, while PPAT and various organizations will assist the head of the land administration division in land registration. Land registration is carried out by formalizing authentic deeds relating to certain legal movements related to land rights and unit property rights, and this legal action is used as an excuse to change the juridical data of private property on registered land.

An authority of the PPAT is to make an authentic deed, which will be used as evidence to prove that there has been a certain legal transfer of land rights and one unit of property rights, and will be used as a land registration statement. Legal action on the rights and property rights of several assets, including: sales and purchases, trade-in, grants, distribution of joint rights; partnership payments (inbreng); granting the right to build/cut off proprietary land; granting mortgage rights; and issue a power of attorney to issue a mortgage.

PPAT has a guarantee for the deed issued in accordance with the PPAT's power of attorney, one of which is stated in Article 40 paragraph (2) PP No. 24 of 1997 which states: "PPAT is obliged to provide a written warning regarding the submission of the deed as mentioned in paragraph (1) to the affiliate concerned." 1

Article 40, paragraph 2 states that the PPAT's responsibility is limited to implementing the deed and submitting a report to the Land Office regarding the deed. After the deed is registered with PPAT, it will be sent directly to the affiliated party. The Land Office determines the registration as a PPAT file and the appropriate PPAT information. The PPAT concerned must notify the appropriate heirs based on the possibility of submitting an application for registration of rights, together with the PPAT law and instructions submitted to the Land Office, and provide a receipt for the heirs or those related to the heirs.

PPAT services as an authorized position are very useful for certain people, especially for people who do not understand the law. Some people who do not understand the law feel unable to handle the legal problems they face, given the limited data around the law. Some people consider the existence of PPAT to be very important and have an obligation to seek answers to environmental problems, especially land law.

\footnotetext{
${ }^{1}$ Ridwan HR, Hukum Administrasi Negara, Jakarta : Rajawali Pers, 2010, p. 14
} 
People who use PPAT administration are usually because they cannot deal with the various factors that are holding them back. These obstacles include, among others, land owners do not understand authoritative techniques, land owners encounter obstacles in the requirements that must be met in obtaining certificates. Some people also feel that these requirements will generally be more difficult and sometimes even too complicated. The current situation makes some communities unfit to complete their own management. Thus, from the various obstacles that exist, land owners who will certify their land refer to PPAT as a mediator to complete the application for utilization for the issuance of land certificates.

The registration process is as an affirmation of verification of rights which is commonly known as a land certificate which makes it a strong thing to show the holder of land rights. Land rights certificates that are allowed will provide meaning and roles for the holders of these rights, which can be used as evidence of land rights, whether there are differences in the valuation of the land in question or can also be used as collateral for payment of bank loans, for example government or private banks having problems with the contract. ${ }^{2}$

In the field of civil law with land instruments as stated in the LoGA and it can be justified that PPAT has a major function in proving a definite crime regarding transfer, the burden of Land Rights is used as the basis for justifying Land Rights Registration. The land within the Directorate General of Agrarian Affairs is currently within the Ministry of Agrarian Affairs and Spatial Planning of the Republic of Indonesia.

For all these functions and purposes, because the making of the deed is not always in accordance with the PPAT deed-making strategy or ignoring the legitimate plan because it can jeopardize the guarantee of land rights, the PPAT concerned must fulfill every requirement that has been determined, especially in making a deed that meets the requirements. essentially as a sincere deed, if the conditions that have been resolved and carried out are in accordance with the framework stipulated in the Regulation of the Head of the National Land Agency Number 1 of 2010 concerning Service Standards and Land Regulations.

Therefore, the registration of the Law on the Transfer of Land Rights must be within the scope of Article 40 Paragraph 1 of Government Decree Number 24 of 1997 (PP Number 24 of 1997) so that disputes in the land sector can be minimized. However, in the registration of land transfer certificates, PPAT does not always meet the time limit stipulated in Article 40(1) of Government Decree

${ }^{2}$ Satjipto Rahardjo, Penegakan Hukum, Yogyakarta : Genta Publishing, 2009, p. 29 
No.24/1997 on Land Registration, which often creates confusion in the land sector. $^{3}$

Because the method of exchanging land rights that has been carried out by PPAT must be completed during the time spent considering the changes in the obligations of the holder of land rights in the certificate and land book if the deed of transfer of rights has been registered, fulfills the requirements that have been completed and is carried out by a framework that has been supervised in the Regulations. Head of BPN No. 1 of 2010 concerning Service Standards and Land Regulations. In the Regulation of the Head of BPN No. 1 of 2006 concerning Provisions for the Implementation of Government Regulation no. 37 of 1998 concerning the Regulation of the Official for Making Land Deeds regulates the suspension in the registration cycle to the land office. What happened to the District Notary or PPAT clearly caused problems related to the weakness of authenticity which could result in losses to the parties involved in the deed.

\section{Research methods}

Research on PPAT's Responsibility for Late Registration of Deeds He Has Made to the Land Office is a type of normative legal study, namely the study of the prevailing laws and regulations in Indonesia. This study can also be regarded as a literature study. In this study, the legal materials used were collections from a literature study. Then an in-depth analysis is carried out in order to be able to answer some of the problem formulations taken in this study. The analysis process in this study uses a descriptive analysis which is the object of this study to make clear the circumstances and conditions. This analysis is also one of the efforts to solve the problems found, and determine the relationship between the problems that have been found in order to find out how to solve them.

\section{Results and Discussion}

\subsection{PPAT's Legal Obligations in Registering the Deed He Has Made to the Office of the National Land Agency}

The guidelines for Article 40 paragraph (2) of Government Regulation Number 24 of 1997 concerning the Registration of Goods are: "PPAT needs to issue a written warning to clarify changes to the documents mentioned in Article (1) previously to clarify Article 40 paragraph (2), namely, PPAT's responsibilities limited to submission of documents together with important documents to the national

\footnotetext{
${ }^{3}$ Liza Mayanti Famaldiana, Implikasi Hukum Keterlambatan Pendaftaran Akta Peralihan Hak Atas Tanah (Studi Di Kantor Pertanahan Kabupaten Bima), Jurnal IUS, Vol IV No. 3, December 2016, p. 509
} 
office. For quick access to matters relating to affiliation, the national office must issue a receipt for submitting a registration application, for example, a deed from the PPAT and submit the file to the appropriate PPAT.

The PPAT involved must notify the legal heirs of the need to apply for a valid sales registration and the PPAT law along with the records at the state office by submitting a receipt. The application for registration of the sale of rights is filled out by the recipient of the right or PPAT or another party who is the recipient of the current right. If it is the recipient of the rights as referred to in Article 40 paragraph 2 of Government Regulation Number 24 of 1997, the documents must be submitted to the office of the Republic of Indonesia before being submitted. At the scene, the PPAT must send a written notification of the placement of documents to the legal heirs to the state office.

Periodic registration of contracts for the transfer of territorial rights carried out by PPAT or PPATS at the regional office of Bima Regency is often not in accordance with the time of contract registration based on Article 40 paragraph 1 of PP 24 of 1997, which is after 7 (seven) working days have elapsed from the date of letter identification. In this case, the PPAT is obliged to submit the law it has promulgated together with related reports to the national office for registration. ${ }^{4}$

According to Government Regulation No. 24 of 1997 concerning Land Registration, this is a legal regulation regulated by property law enforcement officers when carrying out various land registration activities in Indonesia. Submit information on documents submitted at the state office to the relevant subsidiary. This responsibility not only affects the progress of understanding or compliance with the law, but also considers the greater legal impact on PPAT's thoughts or behavior, both positive and negative.

The consistency of PPAT in implementing Article 40 paragraph (2) of PP 24/1997 according to the authority's assessment, can be determined consistency. If the PPAT does not implement the plans as mentioned above, it will generally be called resistance or irregularities and reluctance. Thoughts about consistency, disobedience or deviation and avoidance are closely related to laws that contain restrictions or orders. ${ }^{5}$

\footnotetext{
${ }^{4}$ Habib Adjie, Hukum Notaris Indonesia, Refika Aditama, Bandung, 2008, p. 89

${ }^{5}$ Nicolas Erlich Hetmina, Kedudukan Akta Ppat Yang Terlambat Di Daftarkan Di Kantor Pertanahan Kabupaten/Kota Ketika Ppat Meninggal Dunia, Jurnal Hukum Bisnis Universitas Narotama Surabaya, Vol 2 No. 2, October 2018, p. 107
} 
Registration here is not a requirement for buying and selling land, considering that the sale and purchase of land occurs after the sale and purchase is carried out before the PPAT. Therefore, the sale and purchase of land is legal and closed with the making of the PPAT deed and the PPAT deed is evidence that the sale and purchase has taken place, in particular that the buyer has obtained property rights and trade rights records. in the Agrarian Office is not a requirement for the legitimacy of deals and land acquisitions and trade as well as registration at the Agrarian Office, here only serves to make evidence against third parties or individuals as a whole ${ }^{6}$.

\subsection{Legal Consequences and Responsibilities of PPAT who are late in registering the Deed that has been made to the National Land Agency Office}

Consequences of a legal relationship. Legal relationships provide rights and obligations regulated by law. Therefore, if a violation occurs, the violator can be sued in court or be subject to administrative sanctions for state administrative law. If there is a legal consequence of the PPAT ignoring the written notification of the submission of documents to the Land Office, then Article 62 of Government Regulation Number 24 of 1997 concerning Land Registration regulates administrative sanctions in the form of written documents relating to the dismissal of the PPAT from his position.

Justification for the submission of the PPAT deed in addition to the applicable files to the Land Office for registration. The justification for registration of deeds and records is to maintain the consistency of sincere beliefs to the individual as a whole and to provide a legitimate association. Ordering is an activity that is very difficult to do for creatures controlled by simple passions without using the right reason or point of view, so to complete proper land management is very difficult, therefore professional personnel are needed who are ready to assist the Land Office with commitment and ability that can be demonstrated at work. Given the importance of the deed made by the public official above for people who need legal certainty ${ }^{7}$.

The guiding principle of Article 40 paragraph (2) of Government Decree Number 24 of 1997 concerning Land Registration states: "PPAT is obliged to amend the

\footnotetext{
${ }^{6}$ Deen, Thaufiq., Ong Argo Victoria \& Sumain. (2018). Public Notary Services In Malaysia. JURNAL AKTA: Vol. 5, No. 4, 1017-1026. Retrieved from http://jurnal.unissula.ac.id/index.php/akta/article/view/4135

${ }^{7}$ A Chuasanga, Ong Argo Victoria. (2019). Legal Principles Under Criminal Law in Indonesia Dan Thailand, Jurnal Daulat Hukum, Vol 2, No 1 (2019) http://jurnal.unissula.ac.id/index.php/RH/article/view/4218
} 
law as referred to in paragraph (1) for their respective partners. Considering Article 24 of 1997 Article 40 paragraph (2) of Government Regulation Number 40 paragraph (2) concerning Provisions for Land Registration, PPAT is required to guarantee the convenience of clients in submitting documents to the Land Registration Office, behind it is a performance guarantee. In accordance with PP 24 of 1997 concerning the List of Assets, if there is a possibility that the PPAT uses the power to abuse Article 40 paragraph 2 of the PPAT Government Law, it will be subject to administrative action in the form of a written warning to dismissal from his position as PPAT. ${ }^{8}$

Although the accommodation of the offer deed and land acquisition to the Land Office which was cleared by most PPATs was not in accordance with important laws and regulations, it did not result in the denial of the offer deed and land security. Moreover, to be honest, there are only substantial details which state that delays in presenting the deed of offering and securing the land make the deed in question invalid and invalid and null and void. Even though the accommodation is late, the Head of the Land Office is still obliged to handle it. However, the relevant PPAT is responsible for all consequences, including accidents experienced by the affiliate concerned, which are caused by the delay in sending the archives.

The legal consequences of the expiration of the registration period for the sale of rights do not reduce or damage the validity of the PPAT document. Unregistered PPAT documents are only used for non-defense purposes, so they are not limited to external assurance meetings. This is a real guarantee. Limit the selection of meeting operations. In addition, if PPAT delays the registration of the contract you made, PPAT can request documents with a letter of suspension and will not shorten the contract period for the transfer of rights. In addition, PPAT will not register immediately. If the owner loses the status of the goods, the transfer of rights cannot be registered, and the ownership of the goods becomes the owner, problems will arise. They go to third parties, and external parties can't see if the goods have been confirmed. If the goods are transferred. ${ }^{9}$

Guidelines for legal certainty that guarantees in the land sector require the disclosure of legal instruments that are organized, transparent and clear which are completed reliably in accordance with the spirit and substance of the game

\footnotetext{
${ }^{8}$ Prajitno, Andi, Pengetahuan Praktis Tentang Apa Dan Siapa PPAT, Malang : Selaras, 2013, p. 57

${ }^{9}$ Sukarmi, S., \& Victoria, A. (2018). Cash Waqf in Sustaining Of Indonesian Society "In Legal \&amp; Economic Perspective". AL-ITQAN: JOURNAL OF ISLAMIC SCIENCES AND COMPARATIVE STUDIES, 2(1), 83-97. https://doi.org/10.31436/al-itqan.v2i1.43
} 
plan so that people in carrying out legal actions identical to land become and guarantee land rights certificates. ${ }^{10}$

Responding to the performance of the PPAT, the authors analyze using the theory of authority that cannot be separated from the limitations of the Head of the Land Office for the current situation, the Head of the Land Office as an association that provides a situation to provide guidance and supervision to PPAT in its performance. In accordance with the relevant laws and regulations and further regarding the administrative approval given to the PPAT who filed the negligence mentioned above, at that time the settlement regarding the delay in submitting the land registration file was completed by the PPAT to the Land Office. The Land Office as the authorized agency appointed to manage the implementation of the PPAT presentation must provide directions and warnings,

Because of the importance of evidence as a way of affirmation that can provide legal certainty and guarantee to the right holder, the making of a deed of transfer of land rights as a reason to follow land registration data through the sale and purchase of land rights must be in accordance with the timeframe previously specified in Article 40 paragraph (1) Government Regulation Number 24 of 1997 concerning Land Registration. ${ }^{11}$

By not making a deed of transfer of land rights in accordance with a predetermined period of time, the change in rights obligations cannot be completed, with the aim that the game plan or recording in the land book is considered to have never changed and there has been a meeting between the parties, so that it cannot provide certification. and legal guarantees that should have been completed by PPAT.

\section{Closing}

The guidelines for Article 40 paragraph (2) of Government Regulation Number 24 of 1997 concerning the Registration of Goods are: "PPAT needs to issue a written warning to clarify changes to the documents mentioned in Article (1) previously to clarify Article 40 paragraph (2), namely, PPAT's responsibilities limited to submission of documents together with important documents to the national office. For quick access to PPAT-related matters, the national office must issue a receipt for submitting a registration application, for example, a deed from the

\footnotetext{
10 Santoso, Urip, Pendaftaran Dan Peralihan Hak Atas Tanah, Surabaya : Prenadamedia Group, 2010, p.39

${ }^{11}$ Kusmaryanto, Gunarto, Pendaftaran Akta Jual Beli Yang Melebihi Jangka Waktu Pendaftaran Tanah Di Kantor Agraria Dan Tata Ruang/Badan Pertanahan Nasional Kota Semarang, Jurnal Akta, Vol. 4 No. 3, September 2017, p. 476
} 
PPAT and submit the file to the appropriate PPAT. According to Government Regulation No. 24 of 1997 concerning Land Registration, this is a legal regulation regulated by property law enforcement officers when carrying out various land registration activities in Indonesia. Because of the importance of evidence as a means of affirmation that can provide legal certainty and guarantee to the right holder, the making of a deed of transfer of land rights as a reason to follow land registration data through the sale and purchase of land rights must be in accordance with the timeframe previously specified in Article 40 paragraph (1) Government Regulation Number 24 of 1997 concerning Land Registration. By not making a deed of transfer of land rights in accordance with a predetermined period of time, the change in rights obligations cannot be completed, with the aim that the game plan or recording in the land book is considered to have never changed and there has been a meeting between the parties, so that it cannot provide certification and legal guarantees that should have been completed by PPAT.

\section{References}

Journals:

[1] Kusmaryanto, Gunarto, Pendaftaran Akta Jual Beli Yang Melebihi Jangka Waktu Pendaftaran Tanah Di Kantor Agraria Dan Tata Ruang/Badan Pertanahan Nasional Kota Semarang, Jurnal Akta, Vol. 4 No. 3, September 2017

[2] Liza Mayanti Famaldiana, Implikasi Hukum Keterlambatan Pendaftaran Akta Peralihan Hak Atas Tanah (Studi Di Kantor Pertanahan Kabupaten Bima), Jurnal IUS, Vol IV No. 3, December 2016

[3] Nicolas Erlich Hetmina, Kedudukan Akta PPAT Yang Terlambat Di Daftarkan Di Kantor Pertanahan Kabupaten/Kota Ketika PPAT Meninggal Dunia, Jurnal Hukum Bisnis Universitas Narotama Surabaya, Vol 2 No. 2, October 2018

[4] A Chuasanga, Ong Argo Victoria. (2019). Legal Principles Under Criminal Law in Indonesia Dan Thailand, Jurnal Daulat Hukum, Vol 2, No 1 (2019) http://jurnal.unissula.ac.id/index.php/RH/article/view/4218

[5] Deen, Thaufiq., Ong Argo Victoria \& Sumain. (2018). Public Notary Services In Malaysia. JURNAL AKTA: Vol. 5, No. 4, 1017-1026. Retrieved from http://jurnal.unissula.ac.id/index.php/akta/article/view/4135

[6] Sukarmi, S., \& Victoria, A. (2018). Cash Waqf in Sustaining Of Indonesian Society "In Legal \&amp; Economic Perspective". AL-ITQAN: JOURNAL OF ISLAMIC SCIENCES AND COMPARATIVE STUDIES, 2(1), 83-97. https://doi.org/10.31436/al-itqan.v2i1.43 
Books:

[1] Habib Adjie, 2008, Hukum Notaris Indonesia, Refika Aditama, Bandung

[2] Prajitno, Andi, 2013, Pengetahuan Praktis Tentang Apa Dan Siapa PPAT, Malang : Selaras

[3] Ridwan HR, 2010, Hukum Administrasi Negara, Jakarta : Rajawali Pers

[4] Santoso, Urip, 2010, Pendaftaran Dan Peralihan Hak Atas Tanah, Surabaya: Prenadamedia Group

[5] Satjipto Rahardjo, 2009, Penegakan Hukum, Yogyakarta : Genta Publishing 